
Reference Sources Committee of RUSA's Business Reference and Services Section (BRASS) meets to select Business Reference Sources

\title{
The 2010 Selection of
} Recent Titles

\section{BRASS Business Reference Sources Committee}

\author{
BRASS Business Reference Sources \\ Committee contributing members \\ are Michael Oppenheim, selections \\ editor; Carolyn Fang, nominations \\ coordinator; Nathan Rupp, chair; Anne \\ Bradley; Diane Campbell; David Flynn; \\ Joan Giglierano; Gene Hayworth; \\ Pauly Iheanacho; Peter McKay; and \\ Terry Zarsky. For information contact \\ Michael Oppenheim, Collections and \\ Reference Services Librarian, Rosenfeld \\ Management Library, University of \\ California, Los Angeles 90095-1460; \\ (310) 825-0769; e-mail: moppenhe@ \\ library.ucla.edu.
} since May of the previous year. With all due respect to the familiar and longstanding column title, committee members have come to think of our charge more broadly as finding the most outstanding business information sources, the better to reflect the evolving nature of the formats and means of accessing business information to meet reference needs. For 2010, the committee weeded titles proposed during 2009-10 down to fifteen that made the final review. Among those, the committee selected three as outstanding business information titles and an additional six as noteworthy titles. The works reviewed below cover such areas as economics, the music industry, corporate sustainability, retailing, brand valuation, the current and historical U.S. role in international trade, and an innovative new vehicle for affordable (or free) online access to premier instructional resources in business and economics.

Committee members determine that the final selections for this column meet the conventional definition of reference: a resource compiled specifically to supply information on a certain subject or group of subjects in a form that will facilitate its ease of use. The works are examined for authority and reputation of the publisher, author, or editor; accuracy; appropriate bibliography; organization, comprehensiveness, and value of the content; currency and unique addition to the field; ease of use for intended purpose; quality and accuracy of indexing; and quality and usefulness of graphics and illustrations. Each year more electronic reference titles are published, and additional criteria by which these resources are evaluated include search features, stability of content, graphic design quality, and accuracy of links. Works selected are intended to be suitable for medium to large academic and public libraries.

\section{OUTSTANDING TITLES}

21st Century Economics: A Reference Handbook. Edited by Rhona C. Free. Thousand Oaks, Calif.: Sage, 2010. 2 vols. 1000p. \$325 hardcover (ISBN: 978-1-412-96142-4).

The unprecedented global economic downturn since 2008 has come with many questions that require some knowledge of economics to be properly understood. This reference handbook is significant and timely in providing answers to many of those questions. In two volumes, divided into seven parts, virtually all areas of economics are covered. Volume 1 contains the first five parts: "Scope and 
Methodology of Economics," "Microeconomics," "Public Economics," "Macroeconomics," and "International Economics." Parts 6 and 7 appear in volume 2: "Economic Analyses of Issues and Markets" and "Emerging Areas in Economics."

21st Century Economics: A Reference Handbook broadens the discussion of economics beyond such traditional economic theories as production, distribution, and consumption, extending its range to the consideration of such emerging economic frontiers as neuroeconomics, the economics of happiness, feminist economics, and evolutionary economics. Editor Rhona C. Free, a professor of economics at Eastern Connecticut State University, was the 2004 U.S. Professor of the Year-a prestigious national award from the Carnegie Foundation for the Advancement of Teaching and the Council for Advancement and Support of Education.

The one hundred contributors to this reference, representing a wide array of academic fields and backgrounds, were selected from universities and policy institutes around the globe. The topics covered represent a broad spectrum of economic thought, from the traditional to cutting-edge. There is no lack of divergent opinions. The arrangement of the topics makes reading very easy. Each section is devoted to an area of economic theory, a methodology, or an individual economic issue. One of the greatest strengths of the work is bringing these diverse thoughts together in one resource for the benefit of its readers.

Most chapters follow a similar pattern, starting with a review of the theory, its application and empirical evidence, policy implications, and future directions. The language is readily understandable and avoids unnecessary jargon. Theoretical treatments are followed by concrete examples to illustrate each point. Chapters conclude with references and lists of recommended additional readings.

Those chapters are concise but informative, and presented with deliberate straightforwardness. According to the editor, authors were required to write their analyses using few technical and quantitative tools, and without the use of calculus. This makes the discussion of economic topics easily understandable to those without an economics background.

The turmoil and the challenges in the global economy in recent years have made economics a far less abstract subject to most people than it has been. Seemingly ever-present economic uncertainties spark peoples' interest in the economy and lead to questions about how the economy works. This handbook provides readers with accessible answers to many of the complex economic questions that affect their lives. 21st Century Economics: A Reference Handbook, indeed an outstanding contribution to the field, will benefit a broad range of readers, from undergraduates to advanced researchers, who wish to attain basic knowledge about economic theories and policies and their impact on the economy and peoples' lives.-Pauly Theanacho, University of Delaware, Newark, Delaware

Flat World Knowledge's Open Source Business and Economics Textbooks. Nyack, N.Y.: Flat World Knowledge. www.flatworldknowledge.com (accessed July 31, 2010).

Flat World's open source textbooks are a unique experiment that makes high-quality textbooks freely available: anyone can access textbooks in business and economics and other disciplines at no cost. Access is provided under a Creative Commons license. The license protects the copyright holders while simultaneously allowing anyone to view the content. In addition to business and economics, Flat World's catalog includes textbooks in the humanities and social sciences, the sciences, professional and applied sciences, and mathematics. More than twenty available textbooks cover accounting, economics, finance, information systems, management, marketing, and organizations.

Textbooks can serve as business reference tools to explain basic concepts and theories, explore fields of study, and elucidate how markets and institutions work. For example, Money and Banking, authored by Robert E. Wright (New York University) and Vincenzo Quadrini (University of Southern California), contains a chapter on the financial system. The chapter provides a basic explanation of what a financial system is, the role that it plays in channeling funds from savers and investors to borrowers, and how consumers, entrepreneurs, businesses, and governments put the money to work for personal expenditures, start-up financing, working capital, capital investments, and funding government services. Just as in a good dictionary, the several types of financial markets are defined and explained: equity vs. debt; primary vs. secondary; exchange vs. over-the-counter; and money vs. capital. The textbook advantage is that it locates these institutions in the context of the larger financial system and shows how they interact with it.

Flat World was founded by two executives with much experience working for traditional textbook publishers, including McGraw-Hill, Pearson, and Thomson (now Cengage). They saw a business opportunity in using open source publishing to solve three interrelated problems: textbook affordability for students; instructors' desire to customize textbooks for their courses; and authors' needs to protect their intellectual property. Flat World's business model envisions instructors at colleges and universities adopting these texts for courses to provide students with an affordable alternative to the overpriced print and e-book offerings from traditional publishers. The books are authored by experts, peer-reviewed, and they meet professional standards in organization, content, and illustrations. The free format can be viewed in custom-designed text or full-color PDFs. Students desiring print editions can opt either for purchasing and printing PDF chapters that can be downloaded and printed, or buying an inexpensive black and white edition, or paying a reasonable premium price for a full-color print edition. Each print purchase comes with digital study aids including practice quizzes, digital flash cards of key terms and concepts, and audio study guides, as well as a social learning space in which students can share notes and learn from one another. For example, the "Print-it-Yourself" edition of the financial accounting text is $\$ 34.95$. The black-and-white print edition 


\section{FROM COMMITTEES OF RUSA}

is $\$ 44.95$. The full-color textbook is only $\$ 74.95$. This pricing compares very favorably with traditional textbooks, which can cost $\$ 150$ or more. Bookstores can stock the texts or print them on-demand. Open-source licensing provides instructors with tools to modify the books and create customized editions for their courses. Flat World's publications are outstanding business information sources that take full advantage of the power of the web to publish essential open source textbooks.-Peter Z. McKay, University of Florida, Gainesville

Music Business: The Key Concepts. By Richard Strasser. London, New York: Routledge, 2010. 194p. \$27.95 paperback (ISBN: 978-0-415-99535-1).

The term "music business" might bring to mind thoughts of two disciplines seemingly at odds with one another-after all, what could musicians and MBAs ever have in common? Nevertheless, from the early masters performing for paying patrons through the invention of the phonograph and up to the Recording Industry Association of America's (RIAA) lawsuits against users of Napster and others for freely downloading music online, the worlds of music and business have always been closely intertwined.

Music Business: The Key Concepts is an excellent introduction to nearly two hundred concepts encountered at the intersection of music and business (the complete A-Z list of key concepts covered appears on pages vii- $x$ ). Entries range from terms that are familiar to the layperson (such as "album" or "disc jockey"), to those more familiar to working musicians and their agents (such as "contingent scale payment" or "SoundScan"). Music Business also includes entries about laws pertaining to the industry, such as the Copyright Royalty and Distribution Reform Act of 2004 (CRDRA) and entries for associations involved with the industry, such as the RIAA. The work provides both a historical and a current perspective, as reflected in such entries as "payola" and "peer-to-peer networks." Entries, ranging from a paragraph or two to a couple of pages, include "see also" references and suggestions for further reading. Music Business concludes with an extensive, twenty-four-page bibliography that provides citations fully referencing the recommendations for further reading noted at the end of each entry, and a thorough index.

The author of Music Business, Richard Strasser, is an assistant professor of music industry at Northeastern University. Before taking that position, he was executive sales manager at Stern's Music, a World Music label based in London and New York, and the coordinator of the music business program at the University of Massachusetts Lowell. He has also written The Savvy Studio Owner: A Complete Guide to Setting Up and Running Your Own Recording Studio and The Music and Recording Business: Delivering Music in the 21st Century, so he is wellsuited to write this introduction to music industry concepts.

Music Business joins a couple of other music dictionaries published in the last decade, but this is the first time such a major reference publisher as Routledge has entered the arena. This title is part of Routledge's Key Guides series, which includes other works that discuss fine arts. This estimable pedigree, combined with the low price of Music Business and its availability as an e-book, make the title an excellent addition to the collection of any library receiving questions from patrons doing work in or learning about this industry.- $\mathrm{Na}$ than Rupp, University of Michigan, Ann Arbor

\section{OTHER NOTEWORTHY TITLES}

Berkshire Encyclopedia of Sustainability: Vol. 2: The Business of Sustainability. Edited by Chris Laszlo et al. Great Barrington, Mass.: Berkshire, 2010. 512p. \$135 hardcover (ISBN: 9781-933-78213-3).

The editors state in the introduction to this volume that they encouraged the entry authors to "promote a positive view" of business. This focus is revealed in the eighteen entries on nonenergy industries, which detail the ways in which these industries address sustainability—although their contributions to environmental problems are by no means overlooked. These nonenergy industries include fast food, cement, financial services, and sports, as well as the expected automobile, agriculture, and airline industries. The twelve entries on various energy industries include the familiar solar, nuclear, and wind power industries, as well as the oftenneglected wave and tidal energy industry.

Within the complete list of ninety-nine entries, coverage ranges from "accounting" to "zero waste," and each entry includes recommended sources as well as cross-references. The entries are divided in the reader's guide into six sections, including social issues, finance, technology and design, and regulation. The "leadership" entry, for example, makes the case that the common paradigm of business leadership, focused on concerns such as short-term earnings, has a negative effect on such a broad, long-term issue as sustainability. A new paradigm of leadership is recommended, perhaps transformational, but definitely less hierarchical. This entry provides a good illustration of the scope of this volume, which serves as both a useful first step in research and as a fruitful resource for further thought. It is not necessary to purchase the entire Berkshire Encyclopedia of Sustainability to purchase this valuable volume alone.-Diane Campbell, Rider University, Lawrenceville, New Jersey

The Fairchild Dictionary of Retailing. 2nd ed. By Rona Ostrow. New York: Fairchild, 2009. 471p. $\$ 70$ hardcover (ISBN: 9-781-563-67344-3).

A generation after Rona Ostrow and Sweetman R. Smith published The Dictionary of Retailing in 1985, Ostrow has updated the work to reflect the electronic expansion of retail trade. Drawing from textbooks, glossaries, periodicals, newspapers, and electronic media, the new edition includes more than ten thousand concise, clearly written entries for terms and concepts retailers and students of retailing need to know.

The vocabulary of retailing comes from diverse disciplines, including advertising, marketing, consumer research, psychology, computer science, transportation and distribution, management, and sociology; this judicious compilation 
is a major convenience for users.

Most definitions range in length from a line to a short paragraph, although some topics, such as radio frequency identification (RFID), warrant longer entries. A notable feature of The Fairchild Dictionary of Retailing is abundant cross-referencing, with "see also" references to related entries embedded within definitions, and "see" references for alternative or variant terms provided in the alphabetic listing. Crossreferences provided for common acronyms are particularly valuable, as are the definitions given for slang expressions (for example, "eyeballs" and "open the kimono"). Helpful, too, are the succinct entries that explain the significance in the retailing context of selected federal legislation (for example, the Omnibus Trade and Competitiveness Act and the Nutrition Labeling and Education Act) and U.S. government agencies (such as the Federal Communications Commission and the Food and Drug Administration). Because of space constraints, the biographies of historical figures and most descriptions of retailing associations present in the 1985 dictionary have been omitted.

The Fairchild Dictionary of Retailing belongs in all academic libraries that support undergraduate and graduate marketing and retail management programs, and in large public libraries serving business clientele.—Joan Giglierano, University of Dayton, Dayton, Ohio

The International Brand Valuation Manual: A Complete Overview and Analysis of Brand Valuation Techniques, Methodologies and Applications. By Gabriela Salinas, translated by E. Toder. Chichester: Wiley, 2009. 420p. \$74.50 hardcover (ISBN: 978-047-074031-6).

This new work compiles the state of the field of brand valuation. Gabriela Salinas, is global brand manager for Deloitte Touche Tohmatsu, based in Madrid, Spain, and an acknowledged expert in the field. Although the work is designed for the practitioner, it is also easily comprehensible to the beginning student of brand valuation. The first chapters offer a solid historical and methodological background. Chapter 4 describes the basic approaches to brand valuation-cost, market, or income. The core of the manual is chapter 5, which presents thirty-nine different brand valuation methods. Each two- to five-page entry includes the method description, provider name, and short evaluative comments. Chapter 6 provides different brand classification methods and critiques of those models. The book concludes with an overview of industry trends and observations and recommendations for international ISO (International Organization for Standardization) standards development for brand valuation. Complete "further reading" references provided as a part of each entry, rather than being placed in the index only, would make the book easier to use for those seeking a particular kind of branding method.

The International Brand Valuation Manual offers a comprehensive review of, and practical guide to, the state of brand valuation. This title is an innovative new reference work and a welcome scholarly resource that will be valuable for a wide range of business uses. It is highly recommended for inclusion in accounting, finance, marketing, and intellectual property collections. - Ann M. Fiegen, California State University, San Marcos

Palgrave Macmillan Dictionary of Finance, Investment, and Banking. By Erik Banks. New York: Palgrave Macmillan, 2010. 565p. \$42.95 hardcover (ISBN: 978-0-230-23829-9).

In this era of free online resources such as Investopedianot to mention Wikipedia — why would anybody recommend the purchase of a traditional print dictionary? Well, a recommendation is easy when that dictionary is as affordable and handy as this one is. Compiled by Erik Banks, a longtime practitioner and prolific finance author, the Palgrave Macmillan Dictionary of Finance, Investment, and Banking provides concise definitions, ranging in length from two to ten sentences, written in a nontechnical style. Graphs, figures, and simple financial formulas are sparingly included wherever additional clarification is needed. Aside from traditional financial terms, the dictionary also includes colloquialisms commonly used by investors, accountants, bankers, and other finance professionals. These colloquial terms are clearly marked as such, and they add flair to the otherwise matter-of-fact content.

The dictionary is international in scope; entries for all foreign terms clearly note the country of origin. The inclusion of innovative financial instruments (e.g., "credit default swaps") and hot topics (e.g., "cap and trade") reflects the currency of this publication. Arranged in alphabetical order and packed with cross-references-including those for abbreviationsthis dictionary is very easy to use. Whether your patrons are trying to understand what a "zombie" is, or how a "call on a put" works, this timely reference will be of great use. At $\$ 42.95$, it's an impressive bargain.-Anne Bradley, California State University, Sacramento, California

QFinance. London: Bloomsbury Information. www.qfinance .com (accessed July 31, 2010).

Finance is the beating heart of international commerce, and Qfinance is a remarkable collaboration of some of the finest minds in that field. Qfinance is a free Internet portal to the world of international finance. The most noteworthy feature of the site is that it contains the full contents ( more than two thousand pages) of a companion book published by Bloomsbury. More than three hundred leading experts and specialists contributed entries. Each entry and article are free to view online or download as a high-quality PDF. The Qfinance blog provides timely updates and features on world finance. Qfinance is a joint undertaking of the Qatar Financial Centre Authority and Bloomsbury Publishing. Fueled by extraordinary revenues from its petroleum and natural gas reserves, Qatar's ambition is to become the financial capital of the Middle East. Although there are articles, definitions, and blog posts on Islamic finance, the overwhelming focus is on modern financial theories and best practices in corporate finance, investment, and international financial markets. 


\section{FROM COMMITTEES OF RUSA}

The website, like the book, is organized into nine sections: "Balance Sheets and Cash Flows," "Financial Markets," "Financial Regulation and Compliance," "Funding and Investment," "Governance and Ethics," "Mergers and Acquisitions," "Operations and Performance," "Research Data," and "Financial Reference," including financial quotes, financial information sources, and contributor biographies. Perhaps the best feature is the "Finance Best Practices." Each article begins with a succinct summary, followed by carefully crafted expositions of the topic ranging in length from two to four pages. The articles conclude with selected bibliographies of articles, books, and websites for further study. Checklists accompany the best practices, providing convenient, practical, step-by-step instructions. The best practices are enlivened by "Viewpoint" essays by prominent writers and thinkers that discuss related issues._Peter Z. McKay, University of Florida, Gainesville, Florida

U. S. Trade Issues: A Reference Handbook. By Alfred E. Eckes Jr. Santa Barbara, Calif.: ABC-Clio, 2009. 340p. \$65 hardcover (ISBN: 978-1-598-84199-2).

This well-rounded work is an excellent introduction to the timely topic of trade in the United States. Alfred E. Eckes Jr., former chair and commissioner of the U.S. International Trade Commission, covers the basics of international trade and its role in the global marketplace.

Eckes touches on topics and organizations such as "Leading
Trading Partners and Strategies," the World Trade Organization, and "Alternative Trade Strategies." Each topic includes sections such as "Background and History," "Problems, Controversies, and Solutions," and the "Worldwide Perspective." A twenty-six-page chronology covers major U.S. trade activities (events, legislation, and appointments) from 1776 through 2009. Biographical sketches of twenty-eight notable players throughout the history of U.S. trade range in coverage from such figures as Adam Smith and Alexander Hamilton to Lou Dobbs and Timothy Geithner. Rounding out the work are an extensive section providing data and documents, a fully annotated directory of organizations, and lists of free and feebased resources, covering all publication formats.

This handbook is a great starting point for virtually any investigation of the subject, as it lays the groundwork for a clear understanding of U.S. trade issues. It also provides a handy resource for short presentations on the topic, with its coverage of key terms and the broad-ranging debate over U.S. trade policy. Forty percent of the content is data and documents, including sources for statistics. Available data tables cover U.S. trade in dollars as well as categories of products traded. Each section concludes with an extensive list of resources for further study.

U.S. Trade Issues: A Reference Handbook is highly recommended for beginning university collections as well as public libraries.-_Terry Zarsky, Pikes Peak Library District, Colorado Springs, Colorado 